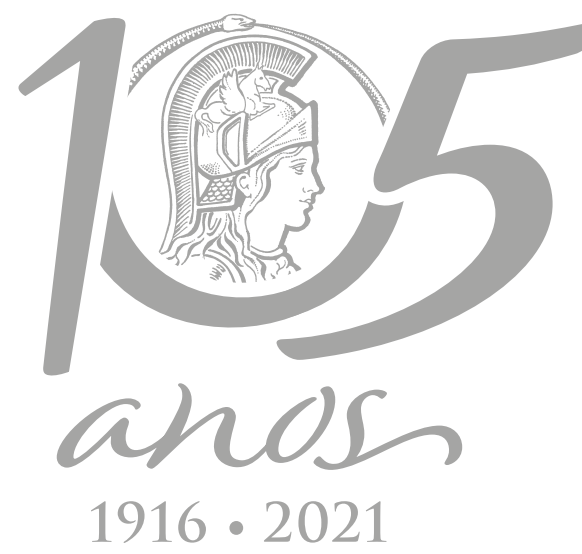

\title{
ECOSYSTEMS
}

\section{Ghost nets: A poorly known threat to Brazilian freshwater biodiversity}

\author{
VALTER M. AZEVEDO-SANTOS, ROBERT M. HUGHES \& FERNANDO M. PELICICE
}

\begin{abstract}
Ghost nets constitute a serious threat to aquatic biodiversity, because they entangle animals as long as they persist in the environment. However, scientific literature in Brazil is virtually silent about this issue in inland ecosystems. Concerned with this gap, we conducted searches on YouTube ${ }^{B R}$ to gather information about ghost nets in Brazilian freshwaters. Through our search, we compiled 33 independent videos showing ghost nets in different aquatic environments. In several cases, we identified entangled animals (i.e., fishes, reptiles, and birds). In this work we also provide recommendations to better understand and mitigate this problem in Brazilian freshwater ecosystems.
\end{abstract}

Key words: Birds, entanglement, fish, fishing, nylon, reptiles.

\section{INTRODUCTION}

The continuous degradation of aquatic ecosystems is a growing concern (e.g., Pelicice et al. 2017, Albert et al. 2021). Pollution, in particular, has attracted mounting attention (e.g., Stelfox et al. 2016, Azevedo-Santos et al. 2019, Giarrizzo et al. 2019, Urbanski et al. 2020) because it has reached multiple aquatic environments and has caused substantial impacts on biodiversity. One important problem is the incorrect disposal or loss of fishing nets (Matsuoka et al. 2005), which creates ghost nets that continuously entangle aquatic animals in the environment (Smolowitz 1978, Iriarte \& Marmontel 2013). Entangled individuals may die in the nets (Blettler \& Wantzen 2019) or suffer injuries, infections, increased predation and reduced growth.

In Brazilian freshwaters, the presence of ghost nets and their effects have been poorly studied (Link et al. 2019). For instance, only one study reported the entanglement and death of animals; two cetaceans in the Amazon basin (Iriarte \& Marmontel 2013). In contrast, several scientific works have been published for Brazilian estuarine and marine ecosystems (e.g., Adelir-Alves et al. 2016, Santos et al. 2012, Chaves 2021). Concerned with this gap, here we report some cases of ghost nets in Brazilian freshwaters based on data retrieved from the internet.

\section{MATERIALS AND METHODS}

Using YouTube ${ }^{\text {BR }}$ (https://www.youtube.com/), we performed searches to find videos reporting ghost nets in Brazilian freshwaters. The searches occurred on 02 July 2020 and 24 September 2020, using the following keywords: "rede de pesca perdida" ("lost fishing net"), "rede de pesca abandonada" ("abandoned fishing net"), "redes fantasmas + rios" (ghost nets + rivers), "rede de pesca abandonada + rios" ("abandoned fishing net + rivers"), and "rede de pesca abandonada + sub" ("abandoned fishing net + sub"). Following methods in Ferraz et al. (2019), we watched all videos to identify animals entangled and the locality. Animals that were not identified at 
taxonomic levels below class were not included in Table I. Those identifications that reached up to species level were performed based on Kullander \& Ferreira (2006) and Ota et al. (2018).

\section{RESULTS}

We found 33 videos showing the presence of ghost nets in different waterbodies, from streams to reservoirs (see Supplementary Material). The identified entangled animals included fishes, reptiles, and birds (Table I). In addition, most records of entanglement were in the upper Paraná River system, southeastern Brazil (Table I).

\section{DISCUSSION}

In general, we found records of entanglement of freshwater fishes, reptiles, and birds. However, other aquatic animals are vulnerable to ghost nets, such as mammals (Iriarte \& Marmontel 2013), amphibians and large reptiles. Our results support the idea that ghost nets constitute a relevant threat in inland waters. In addition, they reveal the importance of YouTube as a source of data about poorly investigated issues (El Bizri et al. 2015, Ferraz et al. 2019) - including pollution. These data are applicable to policies aimed at environmental issues, fishing regulations and social behavior.

Almost all cases of ghost nets occurred in the Upper Paraná system, probably because this basin incorporates one of the most highly populated regions in the country (i.e., São Paulo

Table l. Animal taxa found in ghost nets in Brazilian freshwater ecosystems (based on results in Supplementary Material).

\begin{tabular}{|c|c|c|c|}
\hline Group & Taxa & Number & Watershed \\
\hline Fish & Plagioscion squamosissimus (Heckel 1840) & 1 & Upper Paraná River \\
\hline Fish & Pseudocrenilabrinae & 2 & Upper Paraná River \\
\hline Fish & Cichla kelberi Kullander \& Ferreira 2006 & 1 & Grande River (Upper Paraná River) \\
\hline Fish & Serrasalminae & 3 & Tietê River (Upper Paraná River) \\
\hline Fish & Cichla sp. & 1 & Tietê River (Upper Paraná River) \\
\hline Fish & Cichla sp. & 1 & Uninformed \\
\hline Fish & Hoplias sp. & 1 & Tietê River (Upper Paraná River) \\
\hline Fish & Plagioscion squamosissimus (Heckel 1840) & 2 & Tietê River (Upper Paraná River) \\
\hline Fish & Cichlidae & 22 & Uninformed \\
\hline Fish & Anostomoidea & 1 & São Marcos River (Upper Paraná River) \\
\hline Fish & Characiformes & 3 & Uninformed \\
\hline Fish & Cichla kelberi Kullander \& Ferreira 2006 & 1 & Uninformed \\
\hline Fish & Loricariidae & 1 & Uninformed \\
\hline Fish & Serrasalmus sp. & 1 & Uninformed \\
\hline Fish & Pimelodus maculatus Lacepède 1803 & 1 & Upper Paraná River \\
\hline Reptile & Chelidae & 1 & Upper Paraná River \\
\hline Reptile & Hydromedusa sp. & 1 & Tietê River (Upper Paraná River) \\
\hline Reptile & Hydromedusa sp. & 1 & Uninformed \\
\hline Reptile & Boidae & 1 & Lake (Upper Paraná River) \\
\hline Bird & Anseriformes & 1 & Tietê River (Upper Paraná River) \\
\hline
\end{tabular}


State), where fishing activities (legal and illegal) are common. But this is not a problem restricted to that system. For instance, Iriarte \& Marmontel (2013) found Sotalia fluviatilis Gervais \& Deville, 1853 in a ghost net in the Japurá River, Amazon basin. Therefore, is very likely that other basins in the country (e.g., Doce, São Francisco, Paraíba do Sul) have been similarly affected by ghost nets where fishing activities are common, and inspections are limited (Agostinho et al. 2007).

Different factors may lead to ghost nets in Brazilian freshwater ecosystems, including entanglement and dislocation by large animals such as Capybara (Hydrochoerus hydrochaeris Linnaeus 1766) and Caimans (e.g., Caiman spp.), lost material during fishing trips, intentional abandonment (common during illegal fishing), floods, spates (especially in rivers), incorrect disposal near water bodies, among others. Fishing with nylon nets is an old activity in the country, dating back to the first half of the $20^{\text {th }}$ century (Link et al. 2019). Considering that fishing activities have long been carried out regularly in inland ecosystems (e.g., Iriarte \& Marmontel 2013, Agostinho et al. 2007), ghost nets likely constitute a common and invisible problem in freshwaters.

In addition to ghost fishing (as we showed herein), nets release synthetic polymers into freshwater ecosystems. As the nets degrade, animals may ingest plastic fragments (e.g., Ramos et al. 2012, in estuarine environments). Therefore, Brazilian authorities should care more about ghost nets and respond appropriately.

We have four recommendations regarding this issue. 1) Authorities, citizens and fishers must engage in removing ghost nets from the environment, including the implementation of collaborative projects, funds, and efforts to publicize the problem. Different techniques may be used to locate and remove nets (e.g., Spirkovski et al. 2019). 2) Access to fishing nets should be restricted. Currently, no authorization is required to buy fishing nets in Brazil. Nets are freely sold in stores and in the online market.
3) Education programs must be developed to inform stakeholders and the public about this problem. A public service television announcement could reach many citizens, as would pamphlets distributed to angling groups and sporting goods stores. 4) Researchers must devote attention to this issue and receive adequate funding to investigate the extent of the problem, i.e. quantity, distribution and effects of ghost nets.

\section{Acknowledgments}

We thank three anonymous reviewers for helpful comments. FMP received grants from the Conselho Nacional de Desenvolvimento Científico e Tecnológico/ Brazil (CNPq). RMH received a Fulbright Brasil scholarship.

\section{REFERENCES}

ADELIR-ALVES J, ROCHA GRA, SOUZA TF, PINHEIRO PC \& FREIRE KMF. 2016. Abandoned, lost or otherwise discarded fishing gears in rocky reefs of Southern Brazil. Braz J Oceanogr 64(4): 427-434. https://doi.org/10.1590/ s1679-87592016124806404.

AgOSTINHO A, GOMES LC \& PELICICE FM. 2007. Ecologia e manejo de recursos pesqueiros em reservatórios do Brasil. Maringá: EDUEM, 500p.

ALBERT JS, DESTOUNI G, DUKE-SYLVESTER SM, MAGURRAN AE, OBERDORFF T, REIS RE, WINEMILLER KO \& RIPPLE WJ. 2021. Scientists' warning to humanity on the freshwater biodiversity crisis. Ambio 50: 85-94. https://doi. org/10.1111/j.1523-1739.2005.00701.x.

AZEVEDO-SANTOS VM, GONÇALVES GRL, MANOEL PS, ANDRADE MC, LIMA FP \& PELICICE FM. 2019. Plastic ingestion by fish: A global assessment. Environ Pollut 255: 112994. https:// doi.org/10.1016/j.envpol.2019.112994.

BLETTLER MCM \& WANTZEN KM. 2019. Threats underestimated in freshwater plastic pollution: Mini-Review. Water Air Soil Poll 230(7): 174.

CHAVES PTC. 2021. Danger beyond the catches: a review of conservation threats posed by commercial and non-commercial fisheries in Guaratuba Bay, southern Brazil. Braz J Biol 81: 309-317. https://doi. org/10.1590/1519-6984.225063.

EL BIZRI HR, MORCATTY TQ, LIMA JJS \& VALSECCHI J. 2015. The thrill of the chase: uncovering illegal sport hunting in Brazil through YouTube ${ }^{\mathrm{TM}}$ posts. Ecol Soc 20(3): 30. http:// dx.doi.org/10.5751/ES-07882-200330. 
FERRAZ JD, GARCIA DAZ, CASIMIRO ACR, YABU MHS, GELLER IV, MAGALHÃES ALB, VIDOTTO-MAGNONI AP \& ORSI ML. 2019. Descarte de peixes ornamentais em águas continentais brasileiras registrados no Youtube ${ }^{\mathrm{TM}}$ : Ausência de informação ou crime ambiental deliberado? Rev Bras Zoociências 20(2): 1-20.

GIARRIZZO T, ANDRADE MC, SCHMID K, WINEMILLER KO, FERREIRA M, PEGADO T, CHELAZZI D, CINCINELLI A \& FEARNSIDE PM. 2019. Amazonia: the new frontier for plastic pollution. Front Ecol Environ 17: 309-310. https://doi.org/10.1002/fee.2071.

IRIARTE V \& MARMONTEL M. 2013. River Dolphin (Inia geoffrensis, Sotalia fluviatilis) mortality events attributed to artisanal fisheries in the Western Brazilian Amazon. Aquat Mamm 39(2): 116-124.

KULLANDER SO \& FERREIRA EJG. 2006. A review of the South American cichlid genus Cichla, with descriptions of nine new species (Teleostei: Cichlidae). Ichthyol Explor Freshw 17(4): 289-398.

LINK J, SEGAL B \& CASARINI LM. 2019. Abandoned, lost or otherwise discarded fishing gear in Brazil: A review. Perspect Ecol Conser 17: 1-8.

MATSUOKA T, NAKASHIMA T \& NAGASAWA N. 2005. A review of ghost fishing: scientific approaches to evaluation and solutions. Fish Sci 71(4): 691-702.

OTA RR, DEPRÁ GC, GRAÇA WJ \& PAVANELLI CS. 2018. Peixes da planície de inundação do alto rio Paraná e áreas adjacentes: revised, annotated and updated. Neotrop Ichthyol 16(2): e170094. https://dx.doi. org/10.1590/1982-0224-20170094.

PELICICE FM, AZEVEDO-SANTOS VM, VITULE JRS, ORSI ML, LIMA JUNIOR DP, MAGALHÃES ALB, POMPEU PS, PETRERE JR M \& AGOSTINHO AA. 2017. Neotropical freshwater fishes imperilled by unsustainable policies. Fish Fish 18: 1119-1133.

RAMOS JAA, BARLETTA M \& COSTA MF. 2012. Ingestion of nylon threads by Gerreidae while using a tropical estuary as foraging grounds. Aquat Biol 17: 29-34.

SANTOS AJB, BELLINI C, BORTOLON LF \& COLUCHI R. 2012. Ghost nets haunt the Olive Ridley Turtle (Lepidochelys olivacea) near the Brazilian islands of Fernando de Noronha and Atol das Rocas. Herpetol Rev 43(2): 245-246.

SMOLOWITZ RJ. 1978. Lobster, Homarus americanus, trap design and ghost fishing. Mar Fish Rev 40(5-6): 2-8.

SPIRKOVSKI Z, ILIK-BOEVA D, RITTERBUSCH D, PEVELING R \& PIETROCK M. 2019. Ghost net removal in ancient Lake Ohrid: A pilot study. Fish Res 211: 46-50.

STELFOX M, HUDGINS J \& SWEET M. 2016. A review of ghost gear entanglement amongst marine mammals, reptiles and elasmobranchs. Mar Pollut Bull 111(1-2): 6-17.

URBANSKI BQ, DENADAI AC, AZEVEDO-SANTOS VM \& NOGUEIRA MG. 2020. First record of plastic ingestion by an important commercial native fish (Prochilodus lineatus) in the middle Tietê River basin, Southeast Brazil. Biota Neotrop 20(3): e20201005. http://dx.doi. org/10.1590/1676-0611-bn-2020-1005.

\section{SUPPLEMENTARY MATERIAL}

\section{Results found on YouTube ${ }^{\mathrm{BR}}$ :}

\section{How to cite}

AZEVEDO-SANTOS VM, HUGHES RM \& PELICICE FM. 2022. Ghost nets: A poorly known threat to Brazilian freshwater biodiversity. An Acad Bras Cienc 93: e20201189. DOI 10.1590/0001-3765202120201189.

Manuscript received on July 25, 2020;

accepted for publication on October 25, 2020

\section{VALTER M. AZEVEDO-SANTOS ${ }^{1}$}

https://orcid.org/0000-0001-8986-6406

\section{ROBERT M. HUGHES ${ }^{2,3}$}

https://orcid.org/0000-0003-1308-666X

\section{FERNANDO M. PELICICE}

https://orcid.org/0000-0002-9700-1194

${ }^{1}$ Universidade Estadual Paulista “Júlio de Mesquita

Filho", Departamento de Zoologia, Rua Prof. Dr.

Antonio Celso Wagner Zanin, 250, Distrito de

Rubião Junior, 18618-970 Botucatu, SP, Brazil

${ }^{2}$ Amnis Opes Institute, 2895 SE Glenn, Corvallis, Oregon, USA

${ }^{3}$ Oregon State University, Department of Fisheries, Wildlife,

\& Conservation Sciences, Nash 104, Corvallis, Oregon, USA

${ }^{4}$ Universidade Federal do Tocantins, Núcleo de

Estudos Ambientais, Rua 03, s/n, Jardim dos

Ipês, 77500-000 Porto Nacional, TO, Brazil

Correspondence to: Valter M. Azevedo-Santos

E-mail:valter.ecologia@gmail.com

\section{Author contributions}

VMAS collected data on the social media and elaborated the draft. RMH provided suggestions and helped with writing. FMP provided suggestions and helped with writing. 